\title{
Ex-Patients with COVID-19: Observations after Healing and Its Consequences*
}

\author{
José Humberto Cardoso Resende (1), Aline Correia Barbosa, Arley Braz Gomides, \\ Daniel Asafe Ferreira Rocha, Gabriela Costa Santos, Helena Beatriz Gonçalves Pôrto, \\ Mariana Palmeira Dias De Souza, Rainy da Silva Rogério, \\ Tágara Alessandra Oliveira Kamimura, Emídio Silva Falcão Brasileiro
}

Alfredo Nasser University, Aparecida de Goiânia, GO, Brazil

Email: jresen99@hotmail.com

How to cite this paper: Resende, J.H.C., Barbosa, A.C., Gomides, A.B., Rocha, D.A. F., Santos, G.C., Pôrto, H.B.G., De Souza, M.P.D., da Silva Rogério, R., Kamimura, T. A.O. and Brasileiro, E.S.F. (2021) Ex-Patients with COVID-19: Observations after Healing and Its Consequences. Open Journal of Epidemiology, 11, 31-36. https://doi.org/10.4236/ojepi.2021.111003

Received: November 10, 2020

Accepted: December 20, 2020

Published: December 23, 2020

Copyright $\odot 2021$ by author(s) and Scientific Research Publishing Inc. This work is licensed under the Creative Commons Attribution International License (CC BY 4.0).

http://creativecommons.org/licenses/by/4.0/

\begin{abstract}
During the SARS-Cov-2 or COVID-19 clinical course pandemic of the coronavirus family, we observed symptoms of the respiratory tract, fever, cough, sore throat, and fatigue. The most common symptoms were loss of smell and taste and, when aggravated, it could develop into pneumonia and even death. We selected 40 former COVID-19 patients, who answered a questionnaire with questions about the symptoms and complications after they were cured and which symptoms remained or appeared after the total isolation quarantine for a specific time. Among the answers, the most cited was about "forgetting". Another observation noted was the number of cases in children, which surprised us, considering that, at the beginning of the pandemic, the danger was more related to the elderly population and those with comorbidities.
\end{abstract}

\section{Keywords}

Corona, COVID, Disease, Infection, Pandemic, Pneumonia, Thrombosis

\section{Introduction}

When we had contact with people who had PCR, IGG and IGM altered, indicating the diagnosis of COVID-19 [1], we observed comments that were part of the known or already published clinical complaints as causes of "neurological injuries" and permanent loss of smell [2]. As we have already passed 6 months of the pandemic, we thought it was good to prepare a questionnaire aimed at those considered cured to confirm the clinical diagnoses that have disappeared or not. The surprise was that some of the complaints were not on the list known to epi-

*Work carried out in partnership with Universidade Alfredo Nasser (UNIFAN) with Clínica Brasil. 
demiologists or researchers who were attentive since the beginning of the pandemic [3]. This research was based on information provided by patients only from the Midwest Region of Brazil, more precisely in the State of Goiás, where several cases appeared, with some deaths, between March and September 2020 [4].

During this research, we observed a few answers like no clinical, asymptomatic, or no symptoms. The age of the interviewees ranged from 30 to 60 years old, not including children. There was no conflict of interest, given the care of the team, in addition to having the authorization of all participants, through the informed consent term.

This systematic review shows the potential effects of different types of CoV on the nervous system and describes the range of clinical neurological complications that have been reported so far in COVID-19. We reviewed two hundred and twenty-five studies. Two hundred and eight articles were relevant to COVID-19. The most common neurological complaints in COVID-19 were anosmia, ageusia, and headache, but more serious complications such as stroke, impaired consciousness, seizures, and encephalopathy, were also reported [5].

In the work of Prof. Vakili (2020), he states that the objective of this meta-analysis is to assess the prevalence of the most common symptoms and complications of COVID-19. Thirty studies were in the meta-analysis, including 6389 infected patients. The prevalence of the most common symptoms was: fever, cough, dyspnea, fatigue, and diarrhea. The most prevalent complications were acute respiratory distress syndrome (ARDS), acute cardiac injury, arrhythmia, heart failure, and acute kidney injury (AKI) [6]. In this paper, we observed that $100 \%$ of the cases studied had adverse symptoms.

Prof. Munhoz (2020) aimed to review the literature on neurological complications of SARS-CoV-2 infection. The literature search was carried out following guidelines for systematic reviews, using specific keywords based on the neurological complications of COVID-19 described until May 10, 2020. Forty-three articles were selected, including descriptions ranging from common and nonspecific symptoms, such as hyposmia and myalgia, to more complex and life-threatening conditions, such as cerebrovascular diseases, encephalopathies, and Guillain-Barré syndrome [7].

Prof. Leung (2020) shows the current evidence on short-term damage and assesses the potential long-term damage risk of COVID-19. As a result, different body systems were affected: immune system, respiratory system, cardiovascular system, neurological system, and also cutaneous and gastrointestinal manifestations, liver and kidney failure [8].

\section{Material}

We listen to 40 patients, between 30 and 60 years old, men and women, with positive confirmation after exams of CRP, IGG, IGM, and IGA [9]. In addition to the 4 previous tests mentioned, they had complete blood count, coagulogram, 
urea, creatinine, glucose, cholesterol, and imaging tests. Of the 40 patients, 36 had undergone tomography and 25 had magnetic resonance imaging [10]. In almost all cases, we observed small pulmonary changes, ranging from $30 \%$ to $50 \%$ of the affected lung area. The most common protocol used for treatment was Ivermectin $6 \mathrm{mg}$ (1 tablet for every $30 \mathrm{~kg}$ of body weight per day); Hydroxychloroquine $400 \mathrm{mg}$ ( 1 tablet daily); Azithromycin $500 \mathrm{mg}$ (1 12/12-hour tablet), all for 5 days. Associated with this, they included 1 vitamin D-3 tablet per week; 1 tablet of Vitamin C $1 \mathrm{~g}$ per day; and 1 Zinc tablet $30 \mathrm{~g}$ daily, all for 2 months. Some patients used Acetyl Salicylic Acid (ASA) less frequently; and corticosteroids [11] for cases of pneumonia. We found that patients who had undergone prophylactic treatment with Ivermectin, following the amount according to body weight, even having positive tests for COVID-191 [12], the clinic was non-existent or minimal, with few cases of lung diseases. The general question was: "What are the consequences that you observed after being cured of COVID-19, about": The topics asked were: 1) Brain functions (regarding the organization of reasoning/synthesis capacity/attention/memory); 2) Learning (reading/concentration/memories); 3) Physical and Mental Attitudes (anguish/mood/exercises/work activity/depression); 4) Use of post-treatment medications (the medications they continue to take and others that have been added by the doctor); and 5) Changes in habits and lifestyles (adaptations to everyday tasks).

Regarding the number of times, the words most found in the answers were (Figure 1).

What we do not know is whether the changes present at the moment will disappear or remain as sequels for an indefinite period. During this research, we were unable to measure and affirm changes, such as cardiac involvement, respiratory failure, hypoxemia, vascular disease [13], systemic inflammation, and clinical relapses. Therefore, we opened the field toredo a new questionnaire covering late observations soon. Together with the questionnaire, the selected sample was enough to observe more serious symptoms, but it is important to note that, to date, we have had no cases without any type of complaint.

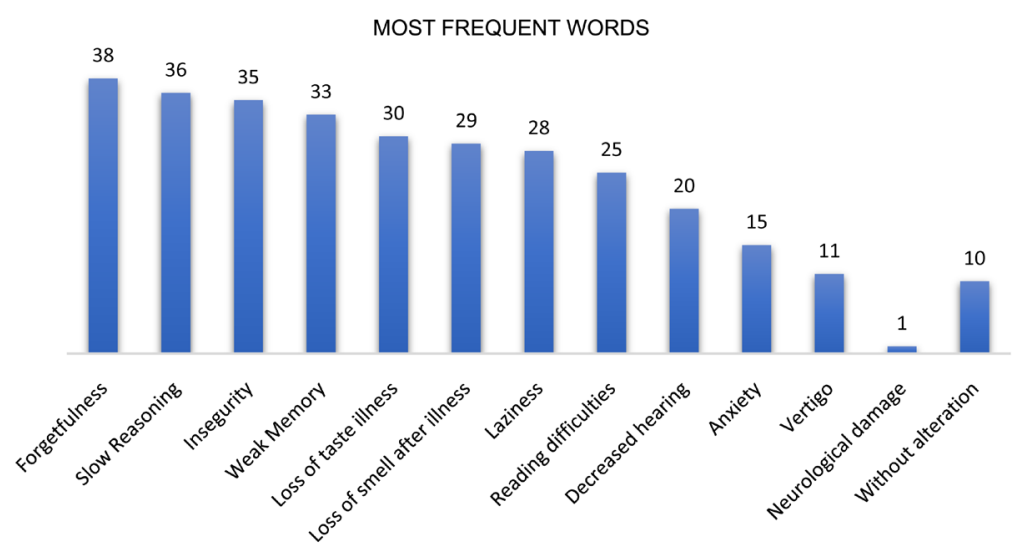

Figure 1. Most frequent words found in the answers. 


\section{Discussion}

The field of discussion is wide because we do not know if the virus has been modified in the laboratory or the virus will respond according to the cases studied to date. In the observation of the patients, when answering the questionnaire, we wrote down some phrases and questions made by the interviewees, which left us in doubt as to how to present them. Here are the most said:

- "I have no attitude!"

- "I’m slower!"

- "I don't feel like anything!"

- "Doctors don't know anything!"

- "I got it from my mother who died!"

- "Why don't they do necropsy of the dead people?"

- "Is death due to viruses or bacteria?"

- "I feel fatigued!"

- "Today, I am a weaker person!"

- "I think it was because I was doing prevention with ivermectin!"

There were a few cases that we heard they did not feel anything. The question that science won't answer for long is how and why this virus came about. What was its intention? Will there be a recurrence? Whoever had it is immune and won't need a vaccine? All of these questions will be the subject of discussion. We are sure that there will still be hundreds of researches on this topic that has affected the world population. We are waiting for the end of the pandemic to prepare an article with a greater number of samples, even though we realized that it is of great value to communicate that cases of post-COVID-19 symptoms have already been detected.

\section{Conclusion}

At the moment, we cannot say that it is a conclusive study, but there were deaths, people cured without sequelae, and people cured with some kind of consequence, because we do not know if, in the future, complaints will appear or diagnoses may be linked to this virus. With more cases studied, we may have more measurement indicators to include in a future article.

We took the opportunity to give our feelings to the families of loved ones who, unfortunately, unable to resist and, on the other hand, congratulations to those who won this fight, overcoming yet another obstacle in life.

We put all the questionnaires answered together with the Informed Consent Term of each patient.

\section{Conflicts of Interest}

The authors declare no conflicts of interest regarding the publication of this paper.

\section{References}

[1] Brazil. (2020) Ministry of Health. Guidelines for the Management of Patients with 
COVID-19. Brasília: 2020.

https://portalarquivos.saude.gov.br/images/pdf/2020/June/18/Covid19-Orientac--o-esManejoPacientes.pdf

[2] da Silveira Cespedes, M. and de Souza, J.C.R.P. (2020) Sars-CoV-2: A Clinical UpdateII. Revista da Associação Médica Brasileira, 66, 547-557.

https://doi.org/10.1590/1806-9282.66.4.547

http://www.scielo.br/scielo.php?script=sci arttext\&pid=S0104-42302020000400547 $\underline{\text { \&lng }=\text { en \&nrm }=\text { iso }}$

[3] Comoli, E. (2020) Sequelae in Patients Recovered from Covid-19 May Persist for a Long Period. Unicamp, 24 de Jul. de 2020.

https://www.unicamp.br/unicamp/noticias/2020/07/24/sequelas-em-pacientes-recu perados-de-covid-19-podem-persistir-por-longo-periodo

[4] Fernandes, F., et al. (2020) Pericardial Diseases in Patients with COVID-19: A Possible Cause of Hemodynamic Deterioration. Arquivos Brasileiros de Cardiologia, 115, 569 573.

http://www.scielo.br/scielo.php?script=sci arttext\&pid=S0066-782X2020001100569 $\underline{\text { \&lng=en\&nrm }=\text { iso }}$

[5] Sharifian-Dorche, M., et al. (2020) Neurological Complications of Coronavirus Infection; a Comparative Review and Lessons Learned during the COVID-19 Pandemic. Journal of the Neurological Sciences, 417, Article No.117085.

https://doi.org/10.1016/j.jns.2020.117085

https://www.jns-journal.com/action/showPdf?pii=S0022-510X\%2820\%2930422-6

[6] Vakili, K., et al. (2020) Critical Complications of COVID-19: A systematic Review and Meta-Analysis Study. medRxiv.

https://doi.org/10.1101/2020.06.14.20130955

https://www.medrxiv.org/content/10.1101/2020.06.14.20130955v1.full.pdf

[7] Munhoz, R.P., Pedroso, J.L., et al. (2020) Neurological Complications in Patients with SARS-CoV-2 Infection: A Systematic Review. Arquivos de Neuro-Psiquiatria, 78, 290 300. https://www.scielo.br/pdf/anp/v78n5/1678-4227-anp-78-05-290.pdf https://doi.org/10.1590/0004-282x20200051

[8] Leung, T.Y.M., Chan, A.Y.L., et al. (2020) Short- and Potential Long-Term Adverse Health Outcomes of COVID-19: A Rapid Review. Emerging Microbes \& Infections, 9, 2190-2199. https://doi.org/10.1080/22221751.2020.1825914 https://www.tandfonline.com/doi/pdf/10.1080/22221751.2020.1825914?needAccess =true

[9] Huyut, M.A. (2020) New Coronavirus Pneumonia and Cardiomyopathy: Case Report. Arquivos Brasileiros de Cardiologia, 114, 843-845.

https://doi.org/10.36660/abc.20200268

http://www.scielo.br/scielo.php?script=sci arttext\&pid=S0066-782X2020000600843 \&lng=pt\&nrm=iso

[10] de Oliveira Lima, C.M.A. (2020) Information about the New Coronavirus Disease (COVID-19). Radiologia Brasileira, 53, 1-2.

https://doi.org/10.1590/0100-3984.2020.53.2e1

http://www.scielo.br/scielo.php?script=sci arttext\&pid=S0100-39842020000200001 \&lng=en\&nrm=iso

[11] Nath, A. and Smith, B. (2020) Neurological Complications of COVID-19: From Bridesmaid to Bride. Arquivos de Neuro-Psiquiatria, 78, 459-460. https://doi.org/10.1590/0004-282x20200121 http://www.scielo.br/scielo.php?script=sci arttext\&pid=S0004-282X2020000800459 \&lng=en\&nrm=iso 
[12] Panamerican Health Organization. (2020) Fact Sheet COVID-19-PAHO and WHO Office in Brazil. https://www.paho.org/pt/covid19

[13] Peters, M.C., Sajuthi, S., Deford, P., et al. (2020) COVID-19-Related Genes in Sputum Cells in Asthma. Relationship to Demographic Features and Corticosteroids. American Journal of Respiratory and Critical Care Medicine, 202, 83-90. https://doi.org/10.1164/rccm.202003-08210C 